\title{
Determinants of Income Diversification Strategies among Agricultural Households in the Philippines using National Survey Data
}

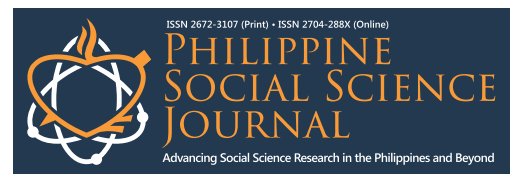

Ferdinand D. Anabo

Capiz State University, Pontevedra, Capiz, Philippines

\section{Article history:}

Submitted: 31 July 2021

Revised: 28 November 2021

Accepted: 21 December 2021

\section{Keywords:}

Economics

Income diversification

Fractional response regression

Agricultural households

Philippines
ABSTRACT. Household income diversification is a critical pathway to improve the living standard of agricultural households. It is the process by which households actively seek to increase the number of income-generating activities. This study sought to describe the prevalence and patterns of income diversification among agricultural households and to identify the factors related to the degree of income diversification. The study applied a quantitative research design using a cross-sectional survey from the Philippine Statistics Authority. The fractional response regression model was used to determine the factors affecting income diversification. Results revealed that most of the household samples have two income sources. Most come from agricultural labor, crop farming, and gardening. Factors related to income diversification are sex, age, education, family size, being married, agricultural income, access to credit, cash support, access to electricity and water, access to information and communication, and vehicle ownership.

\subsection{Introduction}

The agricultural sector is accompanied by immense risk due to low labor absorption, pestilence, drought, diminishing productivity, seasonal production, and employment issues (Agyeman et al., 2014). According to the Philippine Statistics Authority (PSA, 2017), a high percentage of farmers and fishers remained to be poor. For farm and fishing households to survive, they have the option to diversify their income by engaging in other agricultural and non-agricultural activities.

Household income diversification refers to the increase in the sources of income or the balanced contribution of the different sources (Wan et al., 2016). Diversification is a critical pathway to improve the living standard of agricultural households. According to Loison (2015), proactive income diversification strategies can accumulate wealth and enhance the standard of living of farm households. Income diversification facilitates the conversion of unproductive resources to productive resources. Households seek new ways of using existing resources to produce goods and services.

Studies about farmers' income diversification are limited in the Philippines. The country offers an interesting context. The country is archipelagic in nature. Its resources are both land and water, offering households more resources for diversification. However, households are discouraged from formalizing their enterprise because of labor policies, regulations, and registration requirements. Thus, these enterprises become stagnant and do not upgrade to the next level (Hampel-Milagrosa, 2014). Despite these challenges, income diversification is an important starting point for increasing income among households and eventually leading them out of poverty (Cudia et al., 2019). Microenterprises are off-shoots of income diversification strategies that contribute to the local economy and improve the living standards of the households (Quingco \& Leonoras, 2019).

Several empirical studies were conducted about the income diversification of households in other countries. Most studies focused only on a specific source of income, such as non-farm labor and non-farm activities (Osondu, 2014; Sanusi et al., 2016; Shehu \& Abubakar, 2015). Other works focused on counting the number of income sources (Wan et al., 2016). This method does not take into accounts the share of each income source which can be more important. A household can have many sources, but it is not considered diversified if a large share of income comes from one source. Moreover, the samples of these studies are only farm households. Other households relying mainly on other agricultural activities such as fishing, forestry, and hunting were not considered. This study gives importance to all income sources of the households giving a complete picture of income diversification. The use of the income diversification index satisfies this purpose. This study is not only

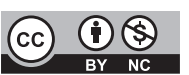

This article published by Philippine Social Science Journal (PSSJ) is licensed under a Creative Commons AttributionNoncommercial 4.0 International (CC BY-NC 4.0). You are free to share (copy and redistribute the material in any medium or format) and adapt (remix, transform, and build upon the material). Under the following terms, you must give appropriate credit, provide a link to the license, and indicate if changes were made. You may do so in any reasonable manner, but not in any way that suggests the licensor endorses you or your use. You may not use the material for commercial purposes. 
limited to farm households but also includes fishing and foraging households. The inclusion of these households gives a more complete representation of agricultural households. This study also extends the literature on income diversification by adding agricultural income as a factor rather than total household income. This variable can reflect the productivity of the agricultural households, which can stimulate income diversification.

The objectives of the study are: (1) to describe the prevalence and patterns of income diversification among agricultural households in the Philippines and; (2) to identify the factors related to the degree of income diversification. The first objective gives details on the: proportion of agricultural households with diversified income, the different income sources of the agricultural households, and the contribution of each income source to the total household income. The second objective aims to explain the reason behind income diversification. Empirical studies reveal that there are demographic and household-level factors that affect income diversification (Osondu, 2014; Sanusi et al., 2016; Shehu \& Abubakar, 2015). Diversification can be stimulated by necessity or opportunity (push and pull factors) (Etea et al., 2020). Some households diversify their income to support their family while others diversify to accumulate wealth.

Policymakers can use the findings of this study in designing a program to make agricultural households more productive. Policymakers are responsible for the necessary rural infrastructure needed by these households to stimulate participation in other economic activities. Higher education institutions can also use the result to design extension programs to develop other income-generating skills of agricultural households. These households must learn new knowledge and skills. With a new set of skills and knowledge, these households will produce other goods and services to supplement their income.

\subsection{Framework of the Study}

This study hypothesizes that demographic and household characteristics are related to the income diversification of agricultural households. This study is informed by the sustainable livelihood framework (SLF) of Ellis (2000). The framework is used to analyze rural household survival strategies. Income diversification is important for households to survive in the rural environment. Agriculture is the main source of income, accompanied by several risks affecting productivity. Relying mainly on agricultural production could result in income shock when there is pestilence, typhoon, drought, and market price drop. Therefore, income diversification is a form of risk management that protects households when crop production fails. Income from other sources allows the household to smooth consumption in times of uncertainty.

The SLF posits that there are five important assets needed for households to diversify income and survive in the rural environment. These assets are human capital, physical capital, social capital, financial capital, and natural capital. Variation in the availability of this capital among households determines the prevalence, pattern, and degree of income diversification. These capitals are primary inputs in the production process. When these capitals are available in the households, they can be encouraged to produce goods and services, thereby increasing their chances of diversifying their income.

The theory is appropriate because it identifies demographic and household characteristics as assets and capital necessary for income diversification. Demographics such as sex, age, and education are considered human capital. Male household heads are potential managers of incomegenerating activities of households. The number of years the individual lives allows the individual to acquire experience and knowledge which can be used to diversify income. Education improves human capital through the acquisition of knowledge and skills from formal institutions. Education improves the entrepreneurial competence of the individual necessary for income diversification (Perez \& Guevarra, 2020).

Machinery and equipment available among households can be considered as physical capital. These assets help convert raw materials into finished products. Examples of physical capital are tractors on a farm, sewing machines, vehicles, and buildings.

The social network of households can be considered a form of social capital. Social networks facilitate coordination and cooperation, which could significantly reduce the cost of doing business. Membership in cooperative and obtaining microfinancing is an example of social capital. Marriage involves sharing of resources among couples that can lead to income diversification. 
Financial capital refers to wealth which primarily includes money, savings, purchasable items, and the likes. These are resources that can be used to start or expand a business. Availability of funds allows farm households with businesses to innovate, diversify and improve human skills.

Natural capital refers to the natural resources to which the household has access. They include land, air, water, living organisms, and all ecosystems in the surroundings necessary for humans to live. Natural capital is the primary source of raw materials.

\subsection{Methods}

This study employed a quantitative research design using cross-sectional survey data. The design is appropriate because the data comes from individual household samples. The variables used were derived from the information contained in the secondary cross-sectional survey data. The variables used in this study are quantitative and measurable. The income diversification index was calculated using the number of income sources and the share of each of these income sources. Moreover, the survey data contain a large sample which enables the researcher to conduct statistical tests. The design allows the researcher to conduct regression analysis.

This study used national cross-sectional survey data from the Philippine Statistics Authority (2015). The data is the 2015 Family Income and Expenditure Survey (FIES) Volume 2. The survey is conducted every three years. The data is divided into four main parts: food expenditure, non-food expenditure, income, and household details. The income section contains information on sources categorized as agricultural, non-agricultural, abroad, domestic, and enterprises. The section on household details contains information about the demographic profile, such as gender, age, marital status, and education of the household head. Other information such as family size, equipment, and gadgets, type of house, electricity, piped water, and access to information and communication (ICT) are also found in this section.

The sample used in this study only includes agricultural households. These are households whose main income comes from agricultural labor, crop farming and gardening, livestock and poultry, fishing, forestry, and hunting. There is a total of 8,701 households classified as agricultural in the 2015 FIES.

This study used descriptive measures to describe the prevalence and patterns of income diversification among agricultural households. Specifically, frequency and percentages were used to examine the distribution of respondents according to the number of income sources, type of income source, and degree of diversification. Mean was used to describe the average contributionof each type of income source.

The degree of income diversification was calculated using the Simpson's Index of Diversity (SID) (Agyeman et al., 2014). The SID considers both the number of income source and their distribution. The formula for the SID is:

$$
S I D=1-\sum_{i=1}^{n} P_{i}^{2}
$$

where SID is the Simpson's Index of Diversity, $\mathrm{n}$ is the number of active income sources, and $\mathrm{P}$ is the proportion of the income coming from the source. The value of the SID lies between 0 to 1 . A value closer to 1 denotes that the household is more diversified. Verbal interpretations of the SID are adopted from Herrera et al. (2018) and Sambuichi et al. (2016). Table 2 presents the interpretation of the SID. The scale used the term "Highly Specialized" to denote non-diversification.

This study analyzes the factors affecting the degree of income diversification using regression analysis. Specifically, the study used the fractional response model. The dependent variable SID is in fractional form ranging from 0 to 1 , which is used to measure the degree of diversification. The use of ordinary least square regression is not appropriate for dependent variables in fractional or proportional form (Ramalho \& da Silva, 2009). 
Table 1. Simpson's Index of Diversity (SID) Scale

\begin{tabular}{|c|c|c|}
\hline Value & $\begin{array}{c}\text { Verbal } \\
\text { Interpretation }\end{array}$ & Description \\
\hline 0 & $\begin{array}{l}\text { Highly } \\
\text { Specialized }\end{array}$ & $\begin{array}{l}50 \% \text { to } 60 \% \text { of income comes from one } \\
\text { source with very minimal contribution } \\
\text { from other sources }\end{array}$ \\
\hline 0.35 & Specialized & $\begin{array}{l}40 \% \text { to } 50 \% \text { of income comes from one } \\
\text { source, with } 2 \text { to } 3 \text { sources contributing } \\
\text { between } 5 \% \text { to } 10 \%\end{array}$ \\
\hline $0.36-0.65$ & Diversified & $\begin{array}{l}30 \% \text { to } 40 \% \text { of income comes from one } \\
\text { source, with } 3 \text { to } 4 \text { sources contributing } \\
10 \% \text { to } 15 \%\end{array}$ \\
\hline 0.66 and above & $\begin{array}{l}\text { Highly } \\
\text { Diversified }\end{array}$ & $\begin{array}{l}4 \text { or more sources contributing } 10 \% \text { to } \\
30 \% \text { of income }\end{array}$ \\
\hline
\end{tabular}

The fractional response model was proposed by Papke and Wooldridge (1996). They suggest a conditional expectation:

$$
E(y \mid \boldsymbol{x}, y \in(0,1])=G(\boldsymbol{x} \gamma)
$$

where $\left.\mathrm{G}^{*}\right)$ is presumed to follow logistic distribution, $\mathrm{y}$ is the dependent variable in proportional form, $x$ are the independent variables, and $\boldsymbol{y}$ are the coefficients to be estimated. Supposing that $y$ follows a Bernoulli distribution conditional on $x, \boldsymbol{y}$ in equation 2 can be estimated by maximizing quasi-likelihood function:

$$
u l(\gamma)=y \log [G(\boldsymbol{x} \gamma)]+(1-y) \log [1-G(\boldsymbol{x} \gamma)]
$$

With the correct specification of equation 2, the quasi-maximum likelihood estimator $\boldsymbol{\gamma}$ is consistent regardless of the distribution of $y$. The model can handle dependent variables that are continuous, discrete, or both. The only critical assumption that needs to be satisfied is the correct specification of equation 2 . This study used the following specification for equation 2 :

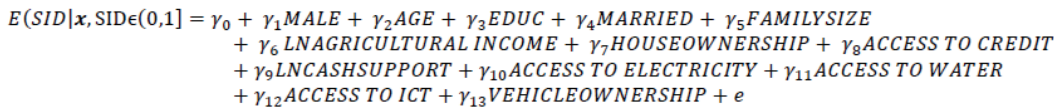

The accuracy of the specification of the fractional response model is tested using Ramsey's regression equation specification error test (RESET). Correct specification and functional form imply that the model did not miss out any important predictors in the model. RESET $p$-value of greater than 0.05 indicates that the functional form and specification of the regression model are correct. The fractional response regression and RESET were done using the software STATA 15.

This study ensures several ethical principles were observed associated with the use of secondary data. First, the household respondents were de-identified before releasing to the researcher. The FIES 2015 data does not contain any identifying information about the sample. The PSA is prohibited by law to provide identifying information in the data they release. Second, it is presumed that there was consent from the household respondent when the survey was taken. Since the Philippine Statistics Authority surveyed in 2015 , it is already understood that there was consent from the respondents. Third, the outcome of this study does not allow for re-identification of the household participants. The methods used in this study do not involve household identification. Only the relevant information about demographics and household characteristics were used. Lastly, the use of this data does not result in any damage and distress. Income diversification is a concept that does not give a negative impression to household respondents. Households practice income diversification strategies to increase their income. This study was also reevaluated by the College's Ethics Review Board and was found to adhere to ethical research principles. 


\subsection{Results and Discussion}

\section{Prevalence and patterns of income diversification}

This section describes the prevalence and patterns of income diversification among agricultural households. Agricultural households were able to show some level of diversification in their income as indicated in the number of income-generating activities, the income share of each source, and degree of income diversification using the Simpson's index of diversity.

Table 2 presents the distribution of households according to the number of income-generating activities. Most of the sample householdsor $35.42 \%$ have 2 income sources, and $23.54 \%$ have 3 income sources. This result reveals that agricultural households were able to somehow increase the number of income sources. However, diversifying further to more than 3 sources of income is highly unlikely, as indicated by a significant reduction of households $(9.13 \%)$. The percentage of households vis-à-vis the number of income sources decreases thereafter. Meanwhile, the number of households who were not able to diversify ( 1 income source) is also significant comprising $29 \%$ of the household samples.

Table 2. Distribution of households by the number of income source

\begin{tabular}{ccc}
\hline Number of Income Source & $f$ & $\%$ \\
\hline 1 & 2,535 & 29.13 \\
2 & 3,082 & 35.42 \\
3 & 2,048 & 23.54 \\
4 & 794 & 9.13 \\
5 & 201 & 2.31 \\
6 & 33 & 0.38 \\
7 & 8 & 0.09 \\
Total & 8,701 & 100 \\
\hline
\end{tabular}

The observed number of income source of the sample households is somewhat similarto Agyeman et al. (2014), who found that farm households, on average, have three combinations of income sources. Diversifying to more than three income sources would require households to commit more resources. Agricultural households have limited resources to allocate more in various income-generating activities.

The type of income-generating activities and their average share of income is presented in Table 3. As expected from agricultural households, more than half of the sample households earn income from agricultural-related activities. Sixty-one percent earns from crop farming and gardening, and $59.48 \%$ sources income from salary and wage from agricultural activities. This income source also has a modest share of the total income of the sample households. Crop farming and gardening have an average income share of $63.45 \%$, and salary and wage from agricultural activities have an average income share of $55.35 \%$. Despite a low level of participation (16.16\%), fishing has the highest average income share (69.01\%) among agricultural sources. This implies that fishermen might have an undiversified source of income and relies mostly on their catch.

The diversification of agricultural households is not only limited to agricultural activities. Results suggest that some have resorted to non-agricultural income sources. Agricultural production is seasonal, and therefore agricultural households must seek an alternative source of income beyond the sector. Table 6 further reveals that $36.10 \%$ were involved in some non-agricultural labor and work. This is followed by wholesale and retail trade with $13.85 \%$ household participation.

This result conforms Agyeman et al. (2014) and Vasco and Tamayo (2017). Agyeman et al. (2014) found that farm households engage in non-farm wage activity aside from agricultural activities. On the other hand, Vasco and Tamayo (2017) found that commerce is the most commonly participated non-farm income-generating activity. These two non-agricultural activities do not require large funding. The households can easily put up retailing activities such as the "sari-sari" store with minimal effort and with no or less government requirement. Other non-agricultural activities such 
Table 3. Distribution of households according to type income source

\begin{tabular}{llll} 
Income Source & $f$ & $\%$ & $\begin{array}{l}\text { Average } \\
\text { Share to } \\
\text { Income }\end{array}$ \\
\hline $\begin{array}{l}\text { Agricultural Sources } \\
\text { Salary and wage from agricultural activities }\end{array}$ & 5175 & 59.48 & 55.35 \\
Crop Farming and Gardening & 5350 & 61.49 & 63.45 \\
Livestock and Poultry Raising & 1539 & 17.69 & 15.15 \\
Fishing & 1406 & 16.16 & 69.01 \\
Forestry and Hunting & 497 & 5.71 & 26.45 \\
\hline Non-Agricultural Sources & & & \\
Salary and wage from non-agricultural activities & 3141 & 36.10 & 23.01 \\
Wholesale and Retail Trade & 1205 & 13.85 & 19.53 \\
Manufacturing & 360 & 4.14 & 12.84 \\
Community, Social, Recreational, and Personal Service & 158 & 1.82 & 14.25 \\
Transportation, Storage and Communication Service & 349 & 4.01 & 19.36 \\
Mining and Quarrying & 28 & 0.32 & 14.42 \\
Construction & 22 & 0.25 & 12.76 \\
Other enterprises not elsewhere classified & 48 & 0.55 & 12.70 \\
\hline
\end{tabular}

*Multiple response

as manufacturing, community and personal services, construction, and mining require capital and specialized skills. Skills and capital are considered barriers to entry that limit the participation of agricultural households in other non-agricultural sectors.

The distribution of households according to the degree of diversification is presented in Table 4. The degree of diversification as represented by the SID is not similar to the number of income sources. A household can have many income sources, but if the bulk of the income comes from only one source, this cannot be considered a highly diversified income. The table reveals that a little over $40 \%$ of the households have "Diversified" income suggesting $30 \%$ to $40 \%$ of income comes from one source, with 3 to 4 sources contributing $10 \%$ to $15 \%$. Almost a third (29.17\%) are classified as "Highly Specialized" or non-diversified income, implying that these households earn more than $50 \%$ to $60 \%$ of their income from one source. Almost $6 \%$ of sample households are classified to have "Highly Diversified" income meaning that these households have at least 4 income sources contributing $10 \%$ to $30 \%$ of income. However, when considering all sample households, the average SID is 0.300 , interpreted as "Specialized," meaning that $50 \%$ of income comes from 1 source with 2 or 3 sources contributing $5 \%$ to $10 \%$. This value is similar to the findings of Agyeman et al. (2014). While some agricultural households managed to diversify their income, the majority remained to have limited sources of income.

Table 4. Distribution of households according to the degree of diversification

\begin{tabular}{lcc}
\hline Simpson's Index of Diversity & $\mathrm{f}$ & $\%$ \\
\hline Highly Specialized & 2,538 & 29.17 \\
Specialized & 1,888 & 21.7 \\
Diversified & 3,775 & 43.39 \\
Highly Diversified & 500 & 5.75 \\
Total & 8,701 & 100 \\
\hline
\end{tabular}

\section{Determinants of income diversification}

Significant factors related to income diversification are presented in this section. Table 8 presents the result of the fractional response model. The results reveal significant coefficients for all variables 
except for house ownership. Among the significant variables, almost all have positive coefficients except for the variables "Male" and "Ln(agricultural income)".

The resulting negative coefficient for the variable "Male" does not support the expectation of the study. The result implies that households headed by a female are more likely to diversify their income more than those headed by a male. This relationship is supported by studies of Dary and Kuunibe (2012), Sanusi et al. (2016), and Vasco and Tamayo (2017). Although this is against the expected relationship, the result is also sensible. Households with no male to support are vulnerable to insufficient income. They may be forced to seek alternative sources of income.

The positive coefficient of "Age" is consistent with the expected relationship based on the framework. Households with older household heads have more diversified income. This supports the human capital argument where experience and knowledge are acquired as an individual increases in age. Experience and knowledge give courage to the individuals to take the risk and engage themselves in other sources of income. This result supports the study of Chawanote (2012). However, it contradicts studies done in the African context, such as Dary and Kuunibe (2012) and Nagler and Naude (2017). Younger individuals are seen to engage more in income diversification in the African context.

All categories of the variable "Education" are positive. To better understand the result, the marginal effects are examined. It can be noted that the marginal effects increase with educational attainment. This implies that as the educational attainment of the household head increases, the degree of income diversification. This result supports the premise of this study. Education develops skills and enhances the knowledge necessary to start an enterprise or seek other sources of income. This result coincides with most empirical studies, such as Alemu and Adesina (2017) and Nagler and Naude (2017).

The positive coefficient for the variable "Married" coincides with the expected relationship. The degree of income diversification is higher among married household heads than those who are single. Marriage forms alliances allowing for the sharing of resources and earnings among two individuals. A working spouse can contribute capital to diversify income. According to Dutta (2007), marriage can also motivate individuals to work more and seek more income sources to provide for the family.

The positive sign of the coefficient of the variable "Family size" conforms to the expectation of this study. Using the argument for human capital, more family members imply that more individuals can work in agricultural and non-agricultural activities. This is similar to the findings of Shehu and Abubakar (2015). They observed a positive relationship between family size and income diversification. Members can contribute funds to start a business. Under the argument of push factors, a larger family size means more mouth to feed. Thus, the family heads will be forced to diversify their income to support the family (Khatun \& Roy, 2012).

Interestingly, the sign for "Ln (agricultural income)" is negative, which contradicts expectations. Logically, households with higher agricultural income are capable of financing other enterprises. However, the negative sign implies that households with higher income have a lower degree of income diversification. Diversification among agricultural households could be due to necessity. Households with higher agricultural income have a lower motivation to diversify their income since they earn enough or more than enough. Meanwhile, those with lower agricultural income are motivated to seek more alternative sources of income to support their family. Agricultural income has limited application in empirical research of income diversification.

Social capital in the form of "Access to credit" is also a critical role in income diversification. The degree of diversification is positively related to access to credit. Households with access to credit can raise funds to finance other income-generating projects. This result conforms with the studies of Shehu and Abubakar (2015) and Alemu and Adesina (2017). Shehu and Abubakar (2015), in particular, observed a positive relationship between formal accessto credit and participation in various income sources. Credit is an important source of business startup funds through loans (Khatun \& Roy, 2012). "Ln (cash_support)" is moderately positively related to income diversification. Households use cash remittance to diversify sources and reduce risk(Siriwardhane \& Amaratunge, 2018).

The estimated positive coefficients of "Access to electricity", "Access to water", and "Access to ICT" support the proposition of this study. These utilities are critical to the income diversification of agricultural households. Electricity and water are important factors of production (Shehu \& Abubakar, 2015). The agricultural household may be motivated to purchase electric-powered machines and equipment to produce goods and services. Access to ICT facilitates the exchange of information 
and expands the network of households. Information on business and production processes can be accessed through ICT (Alemu \& Adesina, 2017; Shehu \& Abubakar, 2015).

Income diversification is positively related to "Vehicle ownership," which supports the expectation of this study. Under the argument of SLF, vehicles are important physical capital (Khatun \& Roy, 2012). Vehicles are considered as productive assets (Agyeman et al., 2014). Households can diversify their income more through the use of vehicles. Vehicles are critical in the transport of goods and services. Vehicles facilitate the transport of individuals to more productive economic areas.

Overall, the sustainable livelihood framework provided a valid basis for identifying the factors affecting thedegree of income diversification among agricultural households. This is further reflected in the $p$-values of the regression equation specification test (RESET), which is greater than 0.05 . This implies that the model does not suffer from specification errors. It implies no variables have been left out from the regression. The variables included are statistically sufficient to make the estimated coefficient consistent and free from bias (Stock \& Watson, 2011).

Table 5. Fractional Response Model

\begin{tabular}{|c|c|c|c|c|}
\hline \multirow{3}{*}{ Independent Variable } & \multirow{3}{*}{ Variable Code/Description } & \multicolumn{3}{|c|}{ Dependent Variable: } \\
\hline & & \multicolumn{3}{|c|}{ Simpson's Index of Diversity(SID) } \\
\hline & & b & se & $\begin{array}{l}\text { Marginal } \\
\text { effects }\end{array}$ \\
\hline Male & 1 if male, 0 otherwise & $-0.133^{* *}$ & 0.056 & -0.027 \\
\hline Age (years) & Actual age of the household head in years & $0.010^{\star \star *}$ & 0.001 & 0.002 \\
\hline \multicolumn{5}{|l|}{ Education } \\
\hline Pre-school & 1 if pre-school, 0 otherwise & $0.874^{\star \star}$ & 0.390 & 0.178 \\
\hline Elementary & 1 if elementary, 0 otherwise & $0.422^{* * *}$ & 0.056 & 0.079 \\
\hline High school & 1 if high school, 0 otherwise & $0.470^{* * *}$ & 0.060 & 0.089 \\
\hline Post high school & 1 if post-high school, 0 otherwise & $0.837^{* \star *}$ & 0.175 & 0.170 \\
\hline College & 1 if college, 0 otherwise & $0.569 * \star *$ & 0.076 & 0.110 \\
\hline Post Baccalaureate & 1 if post-baccalaureate, 0 otherwise & $1.389^{* \star *}$ & 0.344 & 0.301 \\
\hline Married & 1 if married, 0 otherwise & $0.127^{\star \star \star}$ & 0.046 & 0.026 \\
\hline Family size & Actual number of members in the family & $0.088^{\star \star *}$ & 0.006 & 0.018 \\
\hline In(Agricultural Income) & $\begin{array}{l}\text { Natural logarithm of total income from } \\
\text { agricultural activities }\end{array}$ & $-0.528^{\star \star *}$ & 0.025 & -0.107 \\
\hline House Ownership & 1 if own house and lot, 0 otherwise & 0.039 & 0.027 & 0.008 \\
\hline Access to Credit & 1 if loan payment is positive, 0 otherwise & $0.261^{* * *}$ & 0.029 & 0.053 \\
\hline In(Cash Support) & $\begin{array}{l}\text { Natural logarithm of total cash support } \\
\text { from abroad and domestic }\end{array}$ & $0.006^{*}$ & 0.003 & 0.001 \\
\hline Access to electricity & $\begin{array}{l}1 \text { if electricity expenditure is positive, } 0 \\
\text { otherwise }\end{array}$ & $0.325^{* * *}$ & 0.032 & 0.066 \\
\hline Access to water & $\begin{array}{l}1 \text { if water supply expenditure is positive, } 0 \\
\text { otherwise }\end{array}$ & $0.088^{* * *}$ & 0.026 & 0.018 \\
\hline Access to ICT & $\begin{array}{l}1 \text { if communication expenditure is positive, } \\
0 \text { otherwise }\end{array}$ & $0.297^{\star * *}$ & 0.036 & 0.060 \\
\hline Vehicle Ownership & $\begin{array}{l}1 \text { if the household owns any motorized } \\
\text { transportation vehicle, which includes car, } \\
\text { boat, motorcycle, etc., } 0 \text { otherwise }\end{array}$ & $0.286^{\star * *}$ & 0.029 & 0.058 \\
\hline Constant & & $3.090^{* * *}$ & 0.276 & \\
\hline Pseudo R-square & & 0.027 & & \\
\hline Observations & & 8701 & & \\
\hline \multicolumn{5}{|l|}{ RESET $p$-value } \\
\hline LM (2) & & 0.4388 & & \\
\hline $\operatorname{LM}(3)$ & & 0.3281 & & \\
\hline
\end{tabular}




\subsection{Conclusion}

Income diversification is prevalent among agricultural households in the Philippines but in a limited capacity. Most of the households have two sources of income. These income sources are mostly agricultural in nature, such as farm labor and crop gardening and farming. Among nonagricultural sources, retailing and non-farm labor are the most common. Agricultural income sources have the highest contribution to total income. Using a diversity index, many agricultural households have somehow diversified their income to some extent.

Income diversification is related to various demographic and household characteristics. Households with male household head and higher agricultural income is negatively associated with the degree of income diversification. This supports the "push" argument for income diversification. Some households diversify because of necessity brought by lower agricultural income and being a female household head. On the other hand, the variables age, education, marriage, family members, credit, cash support, community infrastructure (electricity, water, and ICT), and vehicle ownership are positively associated with income diversification. These factors are important capital that may stimulate income diversification. Households diversify brought by the opportunities related to these factors.

\section{REFERENCES}

Agyeman, B. A. S., Asuming-Brempong, S., \& Onumah, E. E. (2014). Determinants of income diversification of farm households in the Western Region of Ghana. Quarterly Journal of International Agriculture, 53(1), 55-72. http://ugspace.ug.edu.gh/handle/123456789/25055

Alemu, A. E., \& Adesina, J. O. (2017). In search of rural entrepreneurship: Non-farm household enterprises as instruments of rural transformation in Ethiopia. African Development Review, 29(2), 259-271. https://doi. org/10.1111/1467-8268.12255

Alobo Loison, S. (2015). Rural livelihood diversification in sub-Saharan Africa: A literature review. The Journal of Development Studies, 51(9), 1125-1138. https://doi.org/10.1080/00220388.2015.1046445

Chawanote, C. (2012). Rural Household Non-farm Businesses: Startup, Expansion, Contraction, or Exit? (No. 3232016-11568).

Cudia, C. P., Rivera, J. P. R., \& Jr, Tullao. (2019). Alleviating poverty in the Philippines through entrepreneurship. DLSU Business and Economics Review, 28(3),121-130.

Dary, S. K., \& Kuunibe, N. (2012). Participation in rural non-farm economic activities in Ghana. American International Journal of Contemporary Research, 2(8), 154-161.

Dutta, S. (2007). Non-farm entrepreneurship of farmers in West Bengal: A LISREL/Logit Analysis. Indian Economic Review, 24(2), 231-253. https://www.jstor.org/stable/29793890

Ellis, F. (2000). The determinants of rural livelihood diversification in developing countries. Journal of Agricultural Economics, 51(2), 289-302.

Etea, B. G., Zhou, D., Abebe, K. A., \& Sedebo, D. A. (2020). Is income diversification a means of survival or accumulation? Evidence from rural and semi-urban households in Ethiopia. Environment, Development, and Sustainability, 22(6), 5751-5769. https://doi.org/10.1007/s10668-019-00449-7

Hampel-Milagrosa, A. (2014). Micro and small enterprise upgrading in the Philippines: The role of the entrepreneur enterprise, networks, and business environment. Studies, 86. Bonn: German Development Institute.

Herrera, G. P., Lourival, R., da Costa, R. B., Mendes, D. R. F., Moreira, T. B. S., de Abreu, U. G. P., \& Constantino, M. (2018). Econometric analysis of income, productivity, and diversification among smallholders in Brazil. Land Use Policy, 76(February), 455-459. https://doi.org/10.1016/j.landusepol.2018.02.025

Khatun, D., \& Roy, B. C. (2012). Rural livelihood diversification in West Bengal: Determinants and constraints. Agricultural Economics Research Review, 25(1), 115-124.

Nagler, P., \& Naude, W. (2017). Non-farm entrepreneurship in rural sub-Saharan Africa: New empirical evidence. Food Policy, 67(C), 175-191. https://doi.org/10.1016/j.foodpol.2016.09.019

Osondu, C. K. (2014). Determinants of decision for non-farm entrepreneurship by women farmers in Ikwuano LGA, Abia State. Agrosearch, 14(2), 154-167. https://doi.org/10.4314/agrosh.v14i2.6

Papke, L. E., \& Wooldridge, J. M. (1996). Econometric methods for fractional response variables with an application to 401 (k) plan participation rates. Journal of applied econometrics, 11(6), 619-632.

Perez, D. J. D., \& Guevarra, J. G. (2020). Entrepreneurial competencies and readiness of extension service beneficiaries of a state university. Philippine Social Science Journal, 3(3), 107-118. https://doi.org/10.52006/ main.v3i3.213

Philippine Statistics Authority (2015). 2015 Family income and expenditure survey.

Philippine Statistics Authority (PSA). (2017). Farmers, fishermen, and children consistently posted the highest poverty incidence among basic sectors - PSA. https://psa.gov.ph/ content/farmers-fishermen-and-childrenconsistently-posted-highest-poverty-incidence-among-basic 
Quingco, J. G., \& Leonoras, C. S. (2019). The economic impact, contribution, and challenges of micro business enterprises to the local development. Philippine Social Science Journal, 2(2), 107-122. https://doi. org/10.52006/main.v2i2.84

Ramalho, J., \& da Silva, J. V. (2009). A two-part fractional regression model for the financial leverage decisions of micro, small, medium, and large firms. Quantitative Finance, 9(5), 621-636. https://doi. org/10.1080/14697680802448777

Sanusi, W. A., Dipeolu A. O., \& Momoh, S. (2016). Determinants of participation in non-farm activities among rural households in Osun state- An application of multinomial logit ( $\mathrm{mnl}$ ) model. International Journal of African and Asian Studies, 25, 66-72.

Sambuichi, RHR, Galindo, EP, Pereira, RM, Constantino, M., \& dos Santos Rabetti, M., (2016). Diversidade da Produção nos Estabelecimentos da Agricultura Familiar in Brazil: an econometric analysis based on no cadastro da Declaração de Aptidão ao Pronaf (DAP) (No. 2202). Text for Discussion, Institute of Applied Economic Research (IPEA).

Shehu, A., \& Abubakar, N. (2015). Determinants of participation of farm households in non-farm enterprise activities in rural Nigeria. International Journal of Economics, Commerce and Management, 3(6), 58-71.

Siriwardhane, D., \& Amaratunge, S. (2018). Munich Personal RePEc archive remittances and risk diversification in developing country context : Evidence from Sri Lanka. http://dr.lib.sjp.ac.lk/handle/123456789/8527

Stock, J. H., \& Watson, M. W. (2011). Introduction to econometrics (3rd ed.). USA: Pearson Education Inc.

Vasco, C., \& Tamayo, G.N. (2017). Determinants of non-farm employment and non-farm earnings in Ecuador. CEPAL Review 121, 53-67

Wan, J., Li, R., Wang, W., Liu, Z., \& Chen, B. (2016). Income diversification: A strategy for rural region risk management. Sustainability (Switzerland), 8(10), 1-12. https://doi.org/10.3390/su8101064

\section{Correspondence:}

FERDINAND D. ANABO

drefboana@gmail.com

https://orcid.org/0000-0001-9176-840X 